\title{
The impact of agricultural extension on farmers' technical efficiencies in Ethiopia: A stochastic production frontier approach
}

\begin{tabular}{|c|c|}
\hline \multicolumn{2}{|c|}{$\begin{array}{l}\text { Author: } \\
\text { Kidanemariam G. } \\
\text { Gebrehiwot }\end{array}$} \\
\hline \multicolumn{2}{|c|}{$\begin{array}{l}{ }^{1} \text { College of Economics and } \\
\text { Management Sciences, } \\
\text { University of South Africa, } \\
\text { South Africa }\end{array}$} \\
\hline \multicolumn{2}{|c|}{$\begin{array}{l}{ }^{2} \text { Department of Economics, } \\
\text { Mekelle University, Ethiopia }\end{array}$} \\
\hline \multicolumn{2}{|c|}{$\begin{array}{l}\text { Corresponding author: } \\
\text { Kidanemariam Gebrehiwot, } \\
\text { kg9676@gmail.com }\end{array}$} \\
\hline \multicolumn{2}{|c|}{$\begin{array}{l}\text { Dates: } \\
\text { Received: } 25 \text { Mar. } 2015 \\
\text { Accepted: } 20 \text { Mar. } 2017 \\
\text { Published: } 29 \text { June } 2017\end{array}$} \\
\hline \multicolumn{2}{|c|}{$\begin{array}{l}\text { How to cite this article: } \\
\text { Gebrehiwot, K.G., 2017, } \\
\text { 'The impact of agricultural } \\
\text { extension on farmers' } \\
\text { technical efficiencies in } \\
\text { Ethiopia: A stochastic } \\
\text { production frontier } \\
\text { approach', South African } \\
\text { Journal of Economic and } \\
\text { Management Sciences 20(1), } \\
\text { a1349. https://doi. } \\
\text { org/10.4102/sajems. } \\
\text { v20i1.1349 }\end{array}$} \\
\hline \multicolumn{2}{|c|}{$\begin{array}{l}\text { Copyright: } \\
\text { (C) 2017. The Authors. } \\
\text { Licensee: AOSIS. This work } \\
\text { is licensed under the } \\
\text { Creative Commons } \\
\text { Attribution License. }\end{array}$} \\
\hline \multicolumn{2}{|c|}{ Read online: } \\
\hline 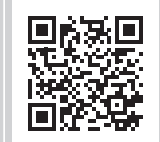 & $\begin{array}{l}\text { Scan this QR } \\
\text { code with your } \\
\text { smart phone or } \\
\text { mobile device } \\
\text { to read online. }\end{array}$ \\
\hline
\end{tabular}

Background: To address the structural food deficit and top down extension system that persisted for decades, the government of Ethiopia has introduced a new extension system, called Participatory Demonstration and Training Extension Systems, which serves more than $80 \%$ of the total population. As the program was streamlined to fit the different agro-climatic condition of the country, the extension approach practiced in the Tigray region (research area) was called Integrated Household Extension Program.

Aim: This article reports on research aimed at measuring the technical efficiency levels of extension participants and non-participants; measuring the impact extension service on technical efficiency.

Setting: The research was conducted in the northern part of the country, where agriculture is the main sources of livelihoods. Moisture is the most critical factor in the production system. The land holding size averages 0.5 ha per household compared to above three ha 30 years ago; indicating the high population pressure in the area.

Methods: A sample of 362 agricultural extension service participants and 369 non-participant farm households from the northern part of Ethiopia, participated in the study. The stochastic production frontier technique was used to analyse the survey data and to compute farm-level technical efficiency.

Results: The results showed an average level of technical efficiency of $48 \%$. It is suggested that substantial gains in output and/or decrease in cost can be attained with the existing technology. All the variables included in the model to explain efficiency were found significant and with the expected sign, except education and number of dependants.

Conclusion: The research tried to assess the impact of a new extension service (participatory in nature) on farmers' productivity in a semi-arid zone, as compared with the conventional extension service and found in the literature areas with relatively better climatic conditions. Hence, if extension administrators could work to uplift the average and below average farmers into better performing farmers level, the overall production and living condition could improve substantially in the research area, and more or less in the rest part of the country.

\section{Introduction}

Ethiopia has a land mass of 1.1 million square kilometres and a potential of 14.03 million hectares of arable land, $85 \%$ of its labour is engaged in agriculture, and there is sufficient rainfall with an annual average precipitation of over $848 \mathrm{~mm}$ per year. In terms of government attention, the sector receives more than $17 \%$ of the annual budget of the country. However, ironically, the country is unable to feed its population; neither can the sector generate a surplus that can be used to finance the development of other sectors [Abrar, Oliver \& Tony 2004; Byerlee et al. 2007; Central Statistical Agency (CSA)2011; Makombe, Dawit \& Aredo 2007; The World Bank 2013].

The main reasons include among other things, an extreme susceptibility to weather variability because of predominantly rain-fed agriculture, poor infrastructure and high population pressure, out-dated production technology and a high illiteracy rate among the farming population (Shiferaw \& Holden 1999).

As a result, the sector's performance in terms of output per worker is $60 \%$ lower and output per hectare is $15 \%$ lower than the sub-Saharan African averages (Pratt \& Yu 2008). To the contrary,

Note: The author, Kidanemariam G. Gebrehiwot, is a Research Associate at the College of Economics and Management Sciences, University of South Africa, South Africa. 
Ethiopia's average fertiliser intensity is $13.2 \mathrm{~kg}$ per hectare and the agricultural labour input is 2204 man days per 1000 ha, which are $46 \%$ and $126 \%$ higher than the sub-Saharan African averages, respectively (Pratt \& Yu 2008).

It was against these realities, after a change of government in 1991, that a new economic policy was formulated and agriculture was given top priority in terms of resource allocation and macro-economic policy [Ministry of Finance and Economic Development (MoFED) 2010; Spielman et al. 2010]. The policy framework is known as the Agriculture Development Led Industrialization (ADLI) strategy. As part of the broader agricultural development strategy, a new extension system called Participatory Demonstration and Training Extension Systems (PADETES) was introduced in 1995 at national level. Later on, the programme was modified by each regional state to fit their situations and the Tigray regional state, in the northern part of Ethiopia, came up with an extension approach called the Integrated Household Extension Program (IHEP) in 2003 [Tigray Bureau of Agriculture and Natural Resource Development (TBoANRD) 2003]. In the formulation process of the new extension programme, an attempt was made not to replicate the shortcomings of the previous extension system (see Alene \& Hassan 2003b; Gebremedhin, Hoekstra \& Tegegne 2006).

Accordingly, the new extension programme was thus developed taking account of the past shortcomings and included the provision of extension services to neglected agro-ecological zones, so as to improve the productivity of smallholder farmers. Moreover, the government has taken policy measures to create a favourable production environment. The most important economy-wide policies have been the devaluation of the domestic currency (the Ethiopian Birr ${ }^{1}$ ), the privatisation of state farms and the withdrawal of preferential treatment in providing subsidised credit and fertiliser, improved seed distribution, deregulating food grain markets and other reform measures focused on 'getting the price right' (Abrar et al. 2004). It is, therefore, timely to assess how the extension service has affected farm productivity (technical efficiency), especially focusing on the semi-arid agro-ecological part of the country.

With this as background, the objective of the research on which this article is based was twofold. Firstly, it aimed to estimate the efficiency levels of farm households in the research areas, in the northern part of Ethiopia. Secondly, it aimed to identify (if any) the determinants of inefficiency variables. Estimating the degree of inefficiency at household level can provide policy makers with information to design programmes and introduce cost-effective efficiency improving measures (in the presence of inefficiency) and long-run development strategies in research and technology generation capacity, so as to address farm productivity in smallholder households. Moreover, it also served as input for development intervention so as to ensure an equitable distribution of income as well as an effective demand structure for other sectors of the economy (Bravo-Ureta \& Pinheiro 1993, 1997).
The article covers the following: a brief review of relevant literature, an empirical model used (a stochastic production frontier approach), discussion of the data sources, area description of the research sites, results and discussion, and conclusions.

\section{Literature review}

The literature on the agricultural extension service and its impact on farm efficiency are mixed. According to Dinar, Karagiannis and Tzouvelekas (2007), the literature dealing with the impact of extension on the performance of farms has followed two different directions. On the one hand, several studies (e.g. Huffman 1977; Jamison \& Moock 1984; Owens, Hoddinott \& Kinsey 2003) have been based on the estimation of a production function in which extension service is considered as a separate input, assuming producers are producing on the same production frontier. In this approach, the impact of extension service on farm performance is evaluated through its marginal product and, in a sense, its direct effect on output is captured. On the other hand, by relaxing the full efficiency assumption, extension service has been used as a factor explaining the differences in the technical efficiency levels among groups of farmers rather than as an input in the production function (e.g. Bravo-Ureta \& Everson 1994; Seyoum, Battese \& Fleming 1998; Young \& Deng 1999). Thus, extension service has been included along with other socio-economic and demographic variables as a factor influencing technical efficiency in farming. As such, the impact of extension service on farm production is indirect and may be evaluated through the potential output gain arising from the elimination of technical inefficiency in farming.

Previous research on the impact of agricultural extension service on efficiency in Ethiopia has produced mixed results. An insignificant effect of extension service on efficiency has been found by Alene and Hassan (2003a), Alene and Zeller (2005) and Bogale and Bogale (2005), but none of these studies were carried out in the highland areas of Tigray. Also, Alene and Hassan (2003a) found an insignificant impact of PADETES in two sites in the eastern part of the country. However, when the extension service was captured via a continuous variable (the number of years the farmer participated in extension programmes), its effects on technical efficiency became positive and significant. Yohannes and Garth (1993) reported higher technical efficiencies for extension participants, but lower allocative efficiencies compared with the non-participant group. Haji (2006) estimated determinants of technical efficiencies for smallholders' vegetable-dominated farming system in eastern Ethiopia. The impact of an agricultural extension service on technical efficiency was found to be negative.

Several variables, including demographic, plot level and institutional variables, are likely to affect the efficiency of smallholder farmers (Alene \& Hassan 2003a; Mathijs \& Vranken 2001). The demographic variables included in our 
estimation are age, gender and level of education of household head and number of dependants. Except for the number of dependants, the three variables (age, gender and education) are expected to affect efficiency positively. Age as proxy for farm experience, higher education level and gender (male) is expected to have a positive effect on farm efficiency (Haji 2006; Mathijs \& Vranken 2001; Tiwari et al. 2008). The second groups of variables are $\operatorname{Iddir}^{2}$ and number of crops grown by the farmer. While the effect of Iddir by enhancing households' access to information is expected to be positively related with efficiency, the effect of crop diversity is difficult to hypothesise a priori. Farmers can grow different crops as a hedge against risks that could occur because of natural calamities (Haji 2006) or, alternatively, growing more crops could add managerial complexity and reduce efficiency. Hence, in view of the educational level and managerial capacity of the rural households in our research areas, it is hypothesised that crop diversity is negatively related with efficiency. Finally, by transferring new skills and information, extension service is expected to affect efficiency positively (Haji 2006; Seyoum et al. 1998). Despite the high number of studies to assess the impact of agricultural extension on productivity in Ethiopia, we could not find a study that had been conducted in the research sites to assess the impact of the new extension service system on farmers' productivity.

\section{Empirical model}

Farmers always operate under uncertainty (caused, e.g. by drought, pests and floods) and it is important to account for this uncertainty in the production process. Therefore, our study employed the stochastic production frontier approach introduced by Battese (1992). Following his specification, the stochastic production frontier can be written as:

$\ln Y_{i}=\beta_{0}+\Sigma \beta_{i} \ln x_{i}+\varepsilon$ where $Y_{i} \geq 0$

[Eqn 1]

where:

- $Y_{i}$ is aggregate output,

- $X_{i}$ is actual input vector,

- $\mathrm{Bi}$ is vector of production function parameters to be estimated,

- $\Sigma \beta_{i} \ln x_{i}$ is the deterministic part, and $\varepsilon$ is the error term.

The total error term $\varepsilon$ in Equation 1 can be further decomposed into two error components as:

$\varepsilon_{i}=V_{i}-U_{i}$ where $U_{i} \geq 0$

where $V_{\mathrm{i}}$ is a symmetrical two-sided normally distributed random error that captures the stochastic effects outside the farmers' control (weather, natural disaster, luck, etc.), measurement errors, and other statistical noise. It is assumed to be independently and identically distributed $V_{\mathrm{i}} \sim N\left(0, \sigma_{v}^{2}\right)$. Thus, $V_{\mathrm{i}}$ allows the production frontier to vary across farms and, therefore, the production frontier is stochastic. The term $U_{i}$ is a one-sided $\left(U_{i} \geq 0\right)$ efficiency component that captures the technical inefficiency of the $i^{\text {th }} \geq 0$ farmer. This component can follow different distributions such as truncated-normal, half-normal, exponential and gamma (Aigner, Knox Lovell \& Schmidt 1977; Greene 2003; Meeusen \& Broeck 1977; Stevenson 1980). For the purpose of this article, it is assumed that $U_{i}$ follows a half-normal distribution $N\left(0, \sigma_{u}^{2}\right)$.

Following Jondrow et al. (1982), technical efficiency (TE) can be estimated as:

$$
T E_{i}=\frac{Y_{i}}{\beta_{0}+\sum \beta_{i} \ln x_{i}+V_{i}}=\exp \left\{-u_{i}\right\}
$$

where $u_{i} \geq 0$

Equation 3 expresses technical efficiency as the ratio of observed output to maximum feasible output, given the random factors experienced by smallholder crop producers. Equation 3 can be functionally specified in its general form as:

$$
U_{i} \mathrm{~F}\left(Z_{i}\right)
$$

where $Z_{i}$ contains all the variables explaining inefficiency at farm operator level.

Finally, the extension service variable is endogenous, that is, whether extension is affecting efficiency and/or inefficiency or efficient and/or inefficient farmers are joining the programme is not clear. Hence, it is suspected that the results suffer from a potential endogeneity problem, so that results should be interpreted with caution.

The linearised Cobb-Douglas production function of Equation 1 was specified as in Equation 5 below and the maximum likelihood was used to estimate input elasticity (Battese \& Coelli 1995):

$\ln Y_{i j}=\beta_{0}+\beta_{1} \operatorname{lnLand}{ }_{\mathrm{ij}}+\beta_{2} \ln \operatorname{Seed}_{\mathrm{ij}}+\beta_{3} \operatorname{lnFertiliser} \mathrm{ij}_{\mathrm{ij}}$ $+\beta_{4} \operatorname{lnManure}_{\mathrm{ij}}+\beta_{5} \operatorname{lnLabour}_{\mathrm{ij}}+\beta_{6} \operatorname{lnOxen}_{\mathrm{ij}}+\beta_{7} \operatorname{lnCapital}_{\mathrm{ij}}+\varepsilon_{\mathrm{ij}}$ [Eqn 5]

where:

- Labour $=$ total person days,

- Seed = total quantity of seeds in Birr,

- Fertiliser = total value of fertilisers in Birr,

- Manure = total quantity in quintal,

- Land = land in tsemad,

- Oxen = total oxen days,

- Capital = estimated value of farm equipment during the survey period in Birr,

- $\quad \beta_{\mathrm{ij}}$ is a vector of $\mathrm{k}$ unknown parameters, $\varepsilon_{\mathrm{ij}}$ is an error term, and

- $Y_{i j}$ denotes the gross value of crop output of the $\mathrm{i}^{\text {th }}$ farmer.

To control the price difference farmers are facing for their produce, one common price (Mekelle's $\mathrm{s}^{3}$ main market price) 3.Mekelle is the capital city of Tigray regional state (the northernmost part of Ethiopia). 
is used. All the specified inputs are hypothesised to influence the level of output positively.

Likewise, technical inefficiency $\left(U_{i}\right)$ can be estimated by subtracting technical efficiency from one $(1-T E)$. Based on the literature, the function of technical inefficiency can be specified as follows:

$U_{\mathrm{ij}}=\delta_{0}+\delta_{1}$ Extension $_{\mathrm{ij}}+\delta_{2}$ Agg $_{\mathrm{ij}}+\delta_{3}$ Gender $_{\mathrm{ij}}$

$+\delta_{4}$ Education $_{\mathrm{ij}}+\delta_{5}$ Dependants $_{\mathrm{ij}}+\delta_{6} \mathrm{NCrops}_{\mathrm{ij}}+\delta_{7}$ Iddir $_{\mathrm{ij}}$

[Eqn 6]

where:

- Age = age of the household head (years),

- Gender = gender of the household head (1=male),

- Education = education level of household head in years,

- NDependants $=$ number of dependants living in the household,

- Ncrops = number of crops farmers produce,

- Iddir = 1 if the household is a member of the social network, and 0 otherwise, and

- Extension $=$ household participation in agricultural extension.

Finally, after conducting all the necessary model selection testing steps, I adopted a Cobb-Douglas stochastic production function for model estimation.

\section{The data and description of the sites}

The data were gathered in a survey conducted during MayJune 2009. The entire sample consisted of 731 households of extension participants and non-participants. The research site, the Geba catchment, ${ }^{4}$ is located in Tigray region ${ }^{5}$ in the northern part of Ethiopia (TBoANRD 2003). The altitudes in the region lie between 300 metres above sea level (MASL) in the east to above 3000 MASL in the northern and central part. Hence, it covers three agro-climatic zones: lowland (kolla) which falls below 1500 MASL, medium highland (woinadega) 1500-2300 MASL and upper highland (douga) 2300-3200 MASL (TBoANRD 2003).

The Geba catchment is one of the catchments in the region and covers an area of 46000 ha, 10 districts (two highland, two lowland and six mid-highland) and 168 sub-districts. To ensure representativeness, the districts were clustered based on their agro-climatic conditions. We randomly selected two districts from the mid-highland, one from the highland and one from the lowland. Two sub-districts were randomly selected from each district.

Households were selected from sub-districts based on population size and farmers' participation status in the agricultural extension service. Accordingly, 360 participants

4.A catchment selected by joint research project between Mekelle University and Inter-University Cooperation (VLIR-UOS) Flemish Project that lasted for 10 years.

5.Region is an administration territory equivalent to Province. District is the nex administration layer/stratum and equivalent to district. Sub-district is the lowes government unit. and 371 non-participant households were selected. Questionnaires were tested and validated before the main survey work. Using the survey questionnaires, demographic, socio-economic, land use and farming system, extension service and other related data were collected. Simple statistical description and econometric models were used to address research objectives, and derive conclusions on the level of technical efficiency and its determinants. The variables used for the analysis are indicated in Table 1.

\section{Results and discussion}

Both descriptive and econometric results are discussed in this section.

\section{Descriptive results}

On comparing the value of crop production of participant and non-participant households, it was seen that participant households produced 66\% more (Birr 13447 compared with Birr 8111) than non-participant households. In terms of input application, participant households used Birr 536 worth of seed, Birr 235 of fertilisers, 75 person days, 5 tsemad of plot size and Birr 808 worth of agricultural equipment during the production year. The corresponding figure for non-participant households is Birr 414 worth of seed, Birr 185 of fertiliser, 56 person days, 3.79 tsemad of plot size and Birr 736. Using a simple statistical comparison of input intensity per output of the two groups, it was seen that participant households consistently showed higher levels of input application than non-participant households. It is very difficult to say anything regarding the efficiency level of the two groups by looking at the absolute volume of production only, as the two groups differed in terms of their input application. However, using the average productivity of each input, it can be inferred that participant households were producing higher levels of output per each unit of input compared with non-participant households.

The variables that are hypothesised to influence farm-level production efficiency are demographic factors such as gender, age, education, number of dependants, agricultural extension service and social network participation status, and number of crops grown by the household. The average age of a farmer was 44 years, indicating that most farmers had a reasonable amount of experience in farming. The average number of years of schooling of the household head was 0.88 years (less than first grade level). This educational level is very low by any standard, which indicates the limited availability of educational facilities in the research sites. In terms of household heads' gender composition, 73\% of the households were headed by men. Participant households grew more diversified crops, on average 3.26 crops, than their counterpart households with an average of 2.78 crops. Social network membership was higher among extension participant households, $29 \%$ compared with $17 \%$ for nonparticipant households. 
TABLE 1: Summary statistics of the variables used in the analysis.

\begin{tabular}{|c|c|c|c|c|c|c|}
\hline \multirow[t]{2}{*}{ Variables } & \multirow[t]{2}{*}{ Description } & \multicolumn{2}{|c|}{ Participants $(n=360)$} & \multicolumn{2}{|c|}{ Non-participants $(n=371)$} & \multirow[t]{2}{*}{$t$-ratio } \\
\hline & & Mean & SE & Mean & SE & \\
\hline InTotal output & Value of crop production of the household (in Birr) & 8.26 & 0.10 & 7.57 & 0.12 & $-4.50 * * *$ \\
\hline \multicolumn{7}{|l|}{ Input variables } \\
\hline InLand & Total land size in tsemad ( 1 tsemad $=0.25$ ha) & 1.39 & 0.14 & 2.98 & 0.15 & $-4.20 * * *$ \\
\hline InSeed & Total expenditure on seed & 5.57 & 0.10 & 4.67 & 0.13 & $-5.55 * * *$ \\
\hline InFertiliser & Total expenditure on fertiliser & & & & & \\
\hline Inmanure & Total quantity in quintal & 2.08 & 0.06 & 1.84 & 0.10 & $-1.75^{*}$ \\
\hline InLabour & Total person days & 3.84 & 0.07 & 3.08 & 0.10 & $-6.69 * * *$ \\
\hline InOxen & Total oxen days employed & 2.60 & 0.05 & 2.16 & 0.06 & $-5.59 * * *$ \\
\hline InCapital & Total value of farm equipment during survey period & 5.96 & 0.08 & 5.10 & 0.11 & $-6.34 * * *$ \\
\hline \multicolumn{7}{|l|}{ Average productivity } \\
\hline Land productivity (output/tsemad) & - & 4202 & 759 & 2601 & 359 & $-1.91 * *$ \\
\hline Seed productivity & - & 37.98 & 6.90 & 24.36 & 3.96 & $-1.71 * *$ \\
\hline Fertiliser productivity & - & 68.23 & 18.95 & 23.29 & 3.57 & $-2.35 * * *$ \\
\hline Capital productivity & - & 122.81 & 61.15 & 33.79 & 5.25 & $-1.46^{*}$ \\
\hline \multicolumn{7}{|l|}{ Inefficiency variables } \\
\hline Age & Household head age in years & 45.06 & 0.67 & 42.87 & 0.83 & $-2.02 * *$ \\
\hline Education & Household head education level in years & 0.90 & 0.07 & 0.84 & 0.07 & -0.64 \\
\hline Dependant & Number of dependants ( $<14 \&>60$ years) & 2.98 & 0.07 & 2.31 & 0.07 & $-6.01 * * *$ \\
\hline Gender & $=1$ if male head and 0 otherwise & 0.80 & 0.02 & 0.66 & 0.02 & $-4.30 * * *$ \\
\hline Number crops & Number of crops produced & 3.26 & 0.07 & 2.78 & 0.07 & $-4.46 * * *$ \\
\hline Iddir & $\begin{array}{l}1=\text { if in the household is a member of a social network, } \\
0 \text { otherwise }\end{array}$ & 0.29 & 0.02 & 0.17 & 0.02 & $-4.23 * * *$ \\
\hline
\end{tabular}

Significant effects are indicated with *, $p<0.1 ; * *, p<0.05 ; * * *, p<0.01$.

TABLE 2: Ordinary least square and maximum likelihood estimates of the stochastic production frontier analysis $(n=731)$.

\begin{tabular}{|c|c|c|c|c|c|c|c|}
\hline \multirow[t]{2}{*}{ Variables } & \multicolumn{4}{|c|}{ Ordinary least square } & \multicolumn{3}{|c|}{ Maximum likelihood estimate } \\
\hline & Coefficient & Estimates & SE & $t$-ratio & Estimates & SE & $t$-ratio \\
\hline Constant & $\beta_{0}$ & 4.63 & 0.21 & $22.38 * * *$ & 7.25 & 0.20 & $36.04 * * *$ \\
\hline Plot size & $\beta_{1}$ & 0.17 & 0.11 & 1.47 & 0.02 & 0.08 & 0.29 \\
\hline Seed & $\beta_{2}$ & 0.03 & 0.04 & 0.64 & 0.01 & 0.04 & 0.23 \\
\hline Fertiliser & $\beta_{3}$ & 0.10 & 0.03 & $3.70 * * *$ & 0.12 & 0.02 & $5.28 * * *$ \\
\hline Manure & $\beta_{4}$ & 0.08 & 0.04 & $2.25 * *$ & 0.07 & 0.03 & $2.13 * *$ \\
\hline Labour & $\beta_{5}$ & 0.10 & 0.08 & 1.22 & -0.03 & 0.06 & -0.50 \\
\hline Oxen & $\beta_{6}$ & 0.48 & 0.10 & $4.70 * * *$ & 0.31 & 0.08 & $3.97 * * *$ \\
\hline Capital & $\beta_{7}$ & 0.17 & 0.04 & $3.91 * * *$ & 0.12 & 0.04 & $3.13 * * *$ \\
\hline Elasticity & - & 1.13 & - & - & 0.65 & - & - \\
\hline \multicolumn{8}{|l|}{ Variance parameters } \\
\hline$\sigma^{2}$ & - & 2.89 & - & - & 25.81 & 3.02 & $8.54 * * *$ \\
\hline$\gamma$ & - & - & - & - & 0.96 & 0.01 & $162.14 * * *$ \\
\hline LR & - & -1442.98 & - & - & -1300.36 & - & - \\
\hline \multicolumn{8}{|c|}{ Maximum likelihood estimates of inefficiency model parameters } \\
\hline Extension & $\delta^{1}$ & -2.14 & 7.11 & $-3.01 * * *$ & - & - & - \\
\hline Age household head & $\delta^{2}$ & -0.20 & 0.05 & $-4.12 * * *$ & - & - & - \\
\hline Gender & $\delta^{3}$ & -7.32 & 0.93 & $-7.88 * * *$ & - & - & - \\
\hline Education & $\delta^{4}$ & 1.79 & 0.16 & $11.05 * * *$ & - & - & - \\
\hline Iddir & $\delta^{5}$ & -11.36 & 1.09 & $-10.44 * * *$ & - & - & - \\
\hline Number of crops & $\delta^{6}$ & -0.46 & 0.21 & $-2.2^{* *}$ & - & - & - \\
\hline Dependants & $\delta^{7}$ & -1.27 & 0.19 & $-6.86 * * *$ & - & - & - \\
\hline
\end{tabular}

Significant effects are indicated with $* *, p<0.05 ; * * *, p<0.01$.

$\mathrm{SE}$, Standard error, LR, likelihood ratio.

\section{Econometrics results}

The first section of Table 2 gives the production functional coefficient estimates which measure the proportional change in output when all inputs included in the model are changed in the same proportion. The functional coefficient for the maximum likelihood estimation (MLE) is 0.65, which indicates that returns to scales are decreasing.
The inputs of fertiliser, manure, oxen and farm equipment (capital) were found to be significant, indicating their importance in crop production in the area, and all were between zero and one (except labour). Based on the estimated coefficients, fertiliser, manure, oxen and farm equipment inputs were the most important variables that affected the level of output in the area. Seed and land size also contributed positively to productivity, although their contributions 
remained marginal and insignificant. On the contrary, labour was found to be insignificant and negative. In the light of the over-populated rural subsistence sector furnished with nearly zero marginal product of labour and working with traditional farm technology, the insignificant and negative coefficient for labour is not surprising (Lewis 1954).

My objective was to understand which variables were the most important factors affecting farmers' production inefficiency. Accordingly, I estimated the technical inefficiency model specified in Equations 3 and 4 using MLE. All my results, except the variable dependants, are consistent with our expectations. The results show that extension and farming experience (age of the household head as proxy) and number of crops were negatively related with inefficiency, implying that participant households in the extension programmes, farmers with higher farming experience and diversified crop growers were more efficient compared with non-participants households, younger farmers and less diversified crop growers, respectively. Our results for extension are in agreement with Seyoum et al. (1998) for maize producers in Ethiopia, Solis, Bravo-Ureta and Quiroga (2008) for hillside farmers of El Salvador and Honduras, and Dinar et al. (2007) for Crete farmers.

As indicated in Table 3, technical indices ranged from $0 \%$ to $84 \%$, with an average of $48 \%$. It is evident from these results that the production and income level of the farming communities can be almost doubled by simply improving farm management practices and without the introduction of new technologies. Compared with the resultsof other similar studies in Africa and other developing countries, myresult is very low. The low level of efficiency can be explained by the low level of education of the farming community, and it indicates that the rural sector is characterised by a traditional, over-populated rural subsistence sector furnished with zero marginal product of labour (Lewis 1954). Moreover, education in my case cannot serve as an ideal indicator for human capital, as the formal education provided in schools does not have practical relevance to the farming system and instead pushes the young and productive forces away from the farm, to seek off-farm employment opportunities (Gedara et al. 2012). Seyoum et al. (1998), comparing technical efficiency between farmers participating in the Sasakawa-Global 2000 project and non-participant farmers in Ethiopia, found 74\% and $88 \%$ inefficiency level, respectively. Alene and Zeller (2005) found an average farmers' efficiency level of 79\% in multiple crop farming in eastern Ethiopia.

Haji (2006) reported an average of 91\% level of efficiency for smallholder vegetable producers in eastern Ethiopia, which is relatively high compared with other studies. A study by Binam et al. (2004) on three crops in Cameroon reported an average efficiency level of 73\%. Mochebelele and WinterNelson (2000), studying the impact of migrant labour on the technical efficiency of coffee farmers in Lesotho, found $36 \%$ for households with no migrant member and $24 \%$ for households with a migrant member. Weir and Knight (2000),
TABLE 3: Frequency distribution of technical efficiency indices.

\begin{tabular}{lccc}
\hline Efficiency score & Total (734) & \% & Cumulative distribution \\
\hline $\mathrm{TE}<0.5$ & 348 & 47.6 & 47.6 \\
$0.5 \leq \mathrm{TE}<0.6$ & 213 & 29.1 & 76.7 \\
$0.6 \leq \mathrm{TE}<0.7$ & 105 & 14.4 & 91.1 \\
$0.7 \leq \mathrm{TE}<0.8$ & 60 & 8.2 & 99.3 \\
$0.8 \leq \mathrm{TE} \leq 0.9$ & 5 & 0.7 & 100 \\
Mean & 0.48 & - & - \\
Minimum & 0.02 & - & - \\
Maximum & 0.82 & - & - \\
\hline
\end{tabular}

$\mathrm{TE}$, technical efficiency.

analysing the impact of education externalities on production and technical efficiency of cereal crop farmers in Ethiopia, found a mean efficiency level of 55\%.

However, the results of this study contradict those of Haji (2006), Alene and Hassan (2003a) and Bogale and Bogale (2005), whose studies were all conducted in Ethiopia.

The positive coefficient and significant effect of education on inefficiency are not surprising. Given that the average educational achievement in the research is below first grade, the stated educational level is too low to bring productivity difference among farmers (Weir \& Knight 2000).

My negative and significant estimated coefficient for the age of the farmer indicates that experienced farmers are more technically efficient compared with their younger counterparts. Similar results were also conveyed by Alene and Hassan (2003a), but our results contradict those of Seyoum et al. (1998). Another interesting finding is the positive coefficient for the number of crops grown by the farmer. Growing diversified crops could contribute to productivity and output level, serving as a hedge against different farm risks and reducing risks, or alternatively diversification could reduce output through its diseconomies of scale effect. This result concurs with the results of Haji (2006) for Ethiopia and Linde-Rahr (2005) for Vietnam and contradicts those of Solis et al. (2008) for Central America and Udry (1996) for Burkina Faso. Hence, the effect of diversification on productivity cannot be known beforehand. In this study, we found a negative relationship with inefficiency, implying that crop diversification ${ }^{6}$ contributes positively to efficiency. Similarly, Iddir (a social capital variable) negatively and significantly affected inefficiency. This could be because of the effect of this variable on access to information and technology, which in turn might have brought differential farm management and efficiencies among the farm households. The negative sign of the dependants' variable is unexpected but, in the context of an agrarian society where dependants actively participate in cattle herding, fetching wood and water and generally contributing positively to the household's economy, the result could be justifiable.

Gender has a negative and statistically significant effect on technical inefficiency, suggesting that male-headed 6.Diversification is measured by the number of crops grown by the household. 
households are more efficient than their female counterparts. The efficiency difference could stem from gender inequalities and female household heads' additional domestic responsibilities (child-rearing and care, cooking and cleaning), which compete for women's time and effort.

\section{Conclusions}

This article addressed two main questions. The first question is whether farmers were producing and managing their farms efficiently, given the available technology. According to the TE estimates, output levels could have been maintained while reducing overall input use by an average of $52 \%$ for the average farmer in the sample and $100 \%$ for the most technically inefficient farmer. The second question that was addressed is which variables explain efficiency differences among farm households. Based on the stochastic frontier estimates, the differences in efficiency were explained by variables such as gender, the number of crops grown and the number of dependants. Extension was found to have a significantly positive effect on efficiency, suggesting that encouraging farmers to participate in the extension programme can enhance productivity and thereby improve the livelihoods of participant households.

This study showed that smallholder farmers' production could potentially be increased by $52 \%$ without increasing other inputs and using current technologies. Although not all factors affecting technical efficiency can be controlled (e.g. age and gender), several areas were identified where policy changes can make an impact. In particular, promoting vocational education (with special emphasis on agricultural skills training) and developing social capital such as Iddir and farmers' associations so as to bridge the gap between technology centres and farmers could help the efficiency level of farm production. To ameliorate the gender-induced efficiency difference, the extension service delivery system needs to be gender-streamlined.

It is suggested that in addition to increasing the availability of technologies and providing quality extension services, access to these aspects should be given due consideration in the future. However, because of the potential endogeneity of extension, this result is only tentative, not conclusive.

\section{Acknowledgements}

The author wishes to express his profound gratitude to VLIRUOS (Belgium) for the full and generous financial support of his PhD study through the MU-IUC programme. The author also sincerely and duly recognises and appreciates the allround support, profound technical comments and advice received from his $\mathrm{PhD}$ study advisors Erik Mathijs and MietMaertens, and his mentor as postdoctoral fellow, Daniel Makina, at the University of South Africa (Unisa). Finally, all the research site farmers who sat patiently for hours to answer the detailed interviews and the enumerators who worked tirelessly to collect the data are also sincerely thanked. The author also wished to thank two PhD advisors who have provided him with guidance and technical support during his $\mathrm{PhD}$ work, including the current article. Especially Prof. Makina, who has specifically supported him in the technical layout of the article and proof reading of the article.

\section{Competing interests}

The author declares that he has no financial or personal relationships that may have inappropriately influenced him in writing this article.

\section{References}

Abrar, S., Oliver, M. \& Tony, R., 2004, 'Aggregate agricultural supply response in Ethiopia: A farm level analysis', Journal of International Development 16(4), 605-620. https://doi.org/10.1002/jid.1110

Aigner, D., Knox Lovell, C.A. \& Schmidt, P., 1977, 'Formulation and estimation of stochastic frontier production function models', Journal of Econometrics 6(1), 62-74. https://doi.org/10.1016/0304-4076(77)90052-5

Alene, A.D. \& Hassan, R.M., 2003a, 'The determinants of farm-level technical efficiency among adopters of improved maize production technology in western Ethiopia', Agekon, Agricultural Economics Research, Policy and Practice in Southern Africa 42(1), 1-14.

Alene, A.D. \& Hassan, R.M., 2003b, 'Measuring the impact of Ethiopia's new extension program on the productive efficiency of farmers', a contributed paper to the 25th international conference of Agricultural Economists, Durban, South Africa, 16-22 August.

Alene, D.A. \& Zeller, M., 2005, 'Technology adoption and farmer efficiency in multiple crops production in eastern Ethiopia: A comparison of parametric and nonparametric distance functions', Agricultural Economics Review 6(1), 5-17.

Aredo, D., 2010, 'The Iddir: An informal insurance arrangement in Ethiopia', Savings and Development 34(1), 53-72.

Battese, G.E., 1992, 'Frontier production functions and technical efficiency: A survey of empirical applications in agricultural economics', Agricultural Economics 7(3), 185-208. https://doi.org/10.1016/0169-5150(92)90049-5

Battese, G.E. \& Coelli, T.J., 1995, 'A model for technical inefficiency effects in a stochastic frontier production functions for panel data', Empirical Economics 20(2), 325-332. https://doi.org/10.1007/BF01205442

Binam, J.N., Tonye, J., Wandji, N., Nyambi, G. \& Akoa, M., 2004, 'Factors affecting the technical efficiency among smallholder farmers in the slash and burn agriculture zone of Cameroon', Food Policy 29(5), 531-545. https://doi.org/10.1016/j. foodpol.2004.07.013

Bogale, T. \& Bogale, A., 2005, 'Technical efficiency of resource use in the production of irrigated potato: A survey of farmers using modern and traditional irrigation schemes in Awi-Zone, Ethiopia', Journal of Agriculture and Rural Development in the Tropics and Subtropics 106(1), 59-70.

Bravo-Ureta, B.E. \& Everson, R.E., 1994, 'Efficiency in agricultural production: The case of peasant farmers in eastern Paraguay', Agricultural Economics 10(1), 27-37. https://doi.org/10.1016/0169-5150(94)90037-X

Bravo-Ureta, B.E. \& Pinheiro, A.E., 1993, 'Efficiency analysis of developing country agriculture: A review of the frontier function literature', Agricultural and Resource Economics Review 22(1), 88-101. https://doi.org/10.1017/ S1068280500000320

Bravo-Ureta, B.E. \& Pinheiro, A.E., 1997, 'Technical, economic, and allocative efficiency in peasant farming: Evidence from the Dominican Republic', The Developing Economies 35(1), 48-67. https://doi.org/10.1111/j.1746-1049.1997.tb01186.x

Byerlee, D., Spielman, D., Alemu, D. \& Gautam, M., 2007, Policies to promote cereal intensification in Ethiopia: A review of evidence and experience, IFPRI Discussion Paper 00707, International Food Policy Research Institute, Kampala, Uganda.

Central Statistical Agency (CSA), 2011, Agricultural sample survey: Report on area and production of major crops, Statistical Bulletin 1, Federal Democratic Republic of Ethiopia, Addis Ababa, Ethiopia.

Dinar, A., Karagiannis, G. \& Tzouvelekas, V., 2007, 'Evaluating the impact of agricultural extension on farm's performance in Crete: A nonneutral stochastic frontier approach', Agricultural Economics 36(2), 135-146. https://doi.org/10.1111/ j.1574-0862.2007.00193.x

Gebremedhin, B., Hoekstra, D. \& Tegegne, A., 2006, Commercialization of Ethiopian agriculture: Extension service from input supplier to knowledge broker and facilitator, Improving productivity and market success (IPMS) of Ethiopia farmers project, Working paper No. 1, IRLI, Nairobi, Kenya.

Gedara, K.M., Wilson, C., Pascoe, S. \& Robinson, T., 2012, 'Factors affecting technical efficiency of rice farmers in village reservoir irrigation systems of Sri Lanka' Journal of Agricultural Economics 63(3), 627-638. https://doi.org/10.1111/ j.1477-9552.2012.00343.x

Greene, W.H., 2003, 'Simulated likelihood estimation of the Normal-Gamma Stochastic Frontier function', Journal of Productivity Analysis 19(2), 179-190. https://doi.org/10.1023/A:1022853416499

Haji, J., 2006, 'Production efficiency of smallholders' vegetable-dominated mixed farming system in eastern Ethiopia: A non-parametric approach', Journal of African Economies 16(1), 1-27. https://doi.org/10.1093/jae/ejl044 
Huffman, W.E., 1977, 'Allocative efficiency: The role of human capital', The Quarterly Journal of Economics 91(1), 59-79. https://doi.org/10.2307/1883138

Jamison, D.T. \& Moock, P.R., 1984, 'Farm education and farm efficiency in Nepal: The role of schooling, extension services, and cognitive skills', World Development 12(1), 67-86. https://doi.org/10.1016/0305-750X(84)90036-6

Jondrow, J., Knox-Lovell, C.A., Materov, I.S. \& Schmidt, P., 1982, 'On the estimation of technical inefficiency in the stochastic frontier production function model', Journa of Econometrics 19(2), 233-238. https://doi.org/10.1016/0304-4076(82)90004-5

Lewis, W.A., 1954, 'Economic development with unlimited supplies of labour', The Manchester School 22(2), 139-191. https://doi.org/10.1111/j.1467-9957.1954. tb00021.x

Linde-Rahr, M., 2005, 'Differences in agricultural returns: An empirical test of efficiency in factor input allocation using Vietnamese data', Agricultural Economics 32(1), 35-45. https://doi.org/10.1111/j.0169-5150.2005.00003.x

Makombe, G., Dawit, K. \& Aredo, D., 2007, 'A comparative analysis of rain fed and irrigated agricultural production in Ethiopia', Irrigation Drainage System 21(1), 35-44. https://doi.org/10.1007/s10795-007-9018-2

Mathijs, E. \& Vranken, L., 2001, 'Human capital, gender and organisation in transition agriculture: measuring and explaining the technical efficiency of Bulgarian and Hungarian farms', Post-Communist Economies 13(2), 171-187. https://doi. org/10.1080/14631370120052654

Meeusen, W. \& Broeck, V.J., 1977, 'Efficiency estimation from Cobb-Douglas production with composed error', International Economic Review 18(2), 435-444. https://doi.org/10.2307/2525757

Ministry of Finance and Economic Development (MoFED), 2006, Ethiopia: Building on progress aplan for accelerated and sustained development to end poverty progress aplan for accelerated
$(P A S D E P)$, Addis Ababa, Ethiopia.

Ministry of Finance and Economic Development (MoFED), 2010, Growth and transformation plan 2010/11-2014/15, volume 1: Main text, Federal Democratic Republic of Ethiopia, Addis Ababa, Ethiopia.

Mochebelele, M.T. \& Winter-Nelson, A., 2000, 'Migrant labour and farm technical efficiency in Lesotho', World Development 28(1), 143-153. https://doi. org/10.1016/S0305-750X(99)00116-3

Owens, T., Hoddinott, J. \& Kinsey, B., 2003, 'The impact of agricultural extension on farm production in resettlement area of Zimbabwe', Economic Development and Cultural Change 51(2), 337-357. https://doi.org/10.1086/346113

Pratt, A. \& Yu, B., 2008, An updated look at the recovery of agricultural productivity in Sub-Saharan Africa, IFPRI Discussion Paper 00787, International Food Policy Research Institute, Washington, DC.
Seyoum, E.T., Battese, G.E. \& Fleming, E.M., 1998, 'Technical efficiency and productivity of maize producers in eastern Ethiopia: A study of farmers within and outside the Sasakawa_Global 2000 project', Agricultural Economics 19(3), 341-348. https:// Sasakawa_Global 2000 project', Agricultural
doi.org/10.1016/S0169-5150(98)00037-1

Shiferaw, B. \& Holden, S., 1999, 'Soil erosion and smallholders' conservation decision in the highlands of Ethiopia', World Development 27(4), 739-752. https://doi. org/10.1016/S0305-750X(98)00159-4

Solis, D., Bravo-Ureta, B.E. \& Quiroga, R.E., 2008, 'Technical efficiency among peasant farmers participating in natural resource management programmes in Central America', Journal of Agricultural Economics 60(1), 202-219. https://doi. org/10.1111/j.1477-9552.2008.00173.x

Spielman, D.J., Byerlee, D., Alemu, D. \& Kelemework, D., 2010, 'Policies to promote cereal intensification in Ethiopia: The search for appropriate public and private roles', Food Policy 35(3), 185-194. https://doi.org/10.1016/j.foodpol.2009.12.002

Stevenson, R.D., 1980, 'Likelihood functions for generalized stochastic frontier estimation', Journal of Econometrics 13(1), 57-66. https://doi.org/10.1016/0304 4076(80)90042-1

The World Bank, 2013, Africa development indicators 2012/13, International Bank for Reconstruction and Development/The World Bank, Washington, DC.

Tigray Bureau of Agriculture and Natural Resource Development (TBoANRD), 2003, Integrated household extension intervention program in Tigray vol. 1, Mekelle, Tigray, Ethiopia.

Tiwari, K.R., Sitaula, B.K., Nyborg, I.L.P. \& Paudel, G.S., 2008, 'Determinants of farmers' adoption of improved soil conservation technology in a middle mountain watershed of central Nepal', Environmental Management 42(2), 210-222. https:// doi.org/10.1007/s00267-008-9137-z

Udry, C., 1996, 'Gender, agricultural production, and the theory of the household', Journal of Political Economy 104(5), 219-255. https://doi.org/10.1086/262050

Weir, S. \& Knight, J., 2000, Education externalities in rural Ethiopia: Evidence from average and stochastic frontier production functions, Working Paper CSAE WWPS/2000.4, Centre for the Study of African Economies, University of Oxford, Oxford

Yohannes, M. \& Garth, C., 1993, Production efficiency and agricultural technologies in the Ethiopian agriculture, Munich Personal RePEc Archive paper no. 404, viewed 29 April 2012, from http://mpra.ub.uni-muenchen.de/404/

Young, D. \& Deng, H., 1999, 'The effects of education in early-stage agriculture: Some evidence from China', Applied Economics 31(11), 1315-1323. https://doi org/10.1080/000368499323193 